studies on the European Communities (including a section on law); member-state relations; external relations; and European security. Additional chapters cover reference sources, official publications, periodicals and recommended holdings for small and private libraries. The volume is indexed by both subject and author.

\title{
INTERNATIONAL CENTRE FOR SETTLEMENT OF INVESTMENT DISPUTES (ICSID)
}

The centre, created in 1966 by the Convention on the Settlement of Investment Disputes between States and Nationals of Other States, provides parties to international investment arrangements with a forum for settling disputes through conciliation and arbitration procedures. ICSID arbitration clauses are now widely used in international investment agreements. An important international organization, the Centre operates in conjunction with the International Bank for Reconstruction and Development. The Centre publishes annual reports. The Thirteenth annual report, describing activities during the 1978-79 fiscal year, was issued recently. It is available from the Centre headquarters at $1818 \mathrm{H}$ Street, N.W., Washington, D.C. 20433, U.S.A. The Centre compiles also a looseleaf service Investment Laws of the World, published commercially by Oceana Publications Ltd., Dobbs Ferry, N.Y., U.S.A.

\section{INTERNATIONAL MONETARY FUND LAW LIBRARY RECENT ACQUISITIONS LIST}

For useful and timely information about new books and articles on international law, international trade and finance law, and comparative law, the attention of readers is directed to the monthly list of acquisitions issued by the Law Library of the International Monetary Fund, 1818 H Street, N.W., Washington, D.C. 20433. A special attraction of this list is its reference to publications which do not appear, as a rule, in publishers' catalogs and advertisements.

The value of acquisition lists is frequently questioned. It is said that they may have a limited in-house application, but that no great benefit can be derived from them by other libraries. However, this is not always the case. Several libraries (the most notable being the Los Angeles County Law Library and the Northwestern University Law Library) publish very helpful lists because their content is intelligently selected and arranged. The acquisition list of the International Monetary Fund Law Library belongs to this category. Legal researchers will find it useful. 


\section{FRENCH MARITIME AND AIR LAW ANNUAL}

Since 1976, the Center of Maritime and Air Law of the Nantes University Law School has published an annual dealing with the legal, economic and political problems of the air and sea, as well as with the newly emerging issues of space law. Annuaire de Droit Maritime et Aerien, as the publication is entitled, is edited by Professor Mircea Mateesco-Matte. It should not be confused with the Annals of Air and Space Law of the McGill University Institute and Center of Air and Space Law in Montreal, Canada, edited by Dr. Nicolas Mateesco Matte. The two publications are completely distinct and contain different materials despite many surface similarities.

Volume IV (1979) of the Annuaire de Droit Maritime et Aerien, which is the most recent issue of this publication, contains about 490 pages. It is available from Editions A. Pedone in Paris, France, for the price of FF 140. The language publication is French.

In order to give an idea of the content of this publication, we list a selection of articles published in volume IV :

René Rodière: La jurisprudence française et la competitivite de nos chantiers dans la concurrence.

Joseph Martray: Premières consequences du drame de l'Amoco-Cadiz sur le droit de la mer et sur l'organisation de la lutte contre la pollution en France.

Michel Bazex: Les problèmes juridiques soulevés par la liaison fluviale Rhin-Main-Danube.

Françoise Moussu-Odier: La circulation maritime et la Conférence sur le droit de la mer.

Charles Knellwolf: La vente FOB et les contrats de transport au Havre.

Vincent Delaporte: Conférence maritime et nouveau code de conduite.

Nicolas Mateesco-Matte: La Convention de Genève relative à la reconnaissance internationale des droits sur l'aéronef, trente ans après.

\section{LEGAL ANTHROPOLOGY}

A useful survey of literature on legal anthropology appears in the last chapter of Order and Dispute: An Introduction to Legal Anthropology by Simon Roberts, published in paperback by Penguin Books in 1979. The author teaches law at the London School of Economics. $\mathrm{He}$ is the author and editor of several works on the tribal laws of Africa. The price of the present book in the United Kingdom is $£ 1.25$. An excellent 